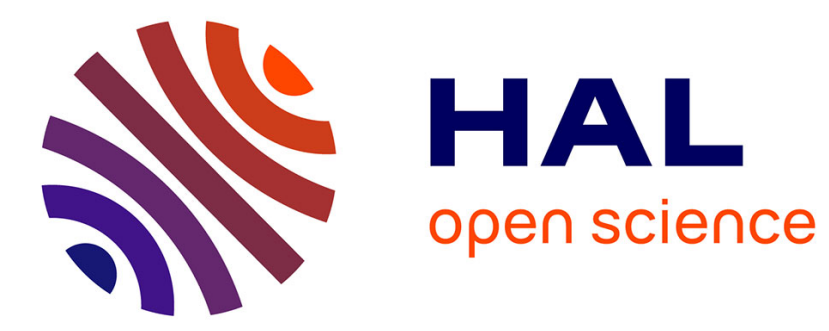

\title{
Composition and correlation criteria of the rhyolitic ignimbrites in the Monts Dore volcanic field (France)
}

Jean-Louis Bourdier, Marion Auxerre, Laurent Arbaret, Michel Pichavant

\section{To cite this version:}

Jean-Louis Bourdier, Marion Auxerre, Laurent Arbaret, Michel Pichavant. Composition and correlation criteria of the rhyolitic ignimbrites in the Monts Dore volcanic field (France). Bulletin de la Société Géologique de France, 2016, 187 (6), pp.261-273. 10.2113/gssgfbull.187.6.261 • insu-01413203

\section{HAL Id: insu-01413203 \\ https://hal-insu.archives-ouvertes.fr/insu-01413203}

Submitted on 11 Jan 2022

HAL is a multi-disciplinary open access archive for the deposit and dissemination of scientific research documents, whether they are published or not. The documents may come from teaching and research institutions in France or abroad, or from public or private research centers.
L'archive ouverte pluridisciplinaire HAL, est destinée au dépôt et à la diffusion de documents scientifiques de niveau recherche, publiés ou non, émanant des établissements d'enseignement et de recherche français ou étrangers, des laboratoires publics ou privés. 
Composition and correlation criteria of rhyolitic ignimbrites from the Monts Dore volcanic field (Massif central, France)

Jean-Louis BOURDIER*, Marion AUXERRE, Laurent ARBARET, Michel PICHAVANT

Institut des Sciences de la Terre d'Orléans, UMR 7327 - CNRS/Université d'Orléans/BRGM, 1A, Rue de la Férollerie, 45071 Orléans Cedex 2, France

*Corresponding author: jean-louis.bourdier@univ-orleans.fr

Key-words: ignimbrite, rhyolite, quartz, tephrostratigraphy, caldera, Massif central 


\begin{abstract}
Rhyolitic pyroclastic units, mostly ignimbrites (ash-and-pumice flow deposits), from plinian eruptions belonging to the early activity (> 2.5 Ma) of the plio-quaternary Monts Dore volcanic field (Massif central, France) are documented, in order to provide a comprehensive set of lithofacies and compositional that could serve as a rational basis for ignimbrite discrimination and tephrostratigraphic correlations. We define or redefine six major pyroclastic units (five ignimbrites and one pumice fallout deposit), based mainly on pumice texture and mineral assemblage. Pumices and quartz-hosted glass inclusions are compositionally rather uniform, being high-silica rhyolites with very low $\mathrm{CaO}, \mathrm{MgO}$ and $\mathrm{FeO}$ contents. Juvenile mineral assemblages are K-feldspar \pm quartz \pm plagioclase with rare biotite \pm amphibole + accessory phases (mostly sphene, zircon, oxides, apatite). The feldspars, biotite and amphibole compositions of all units strongly overlap and are of little help for interunit discrimination. These data provide clues to some volcanological issues under debate in the Monts Dore volcanic field. The major rhyolitic pyroclastics found on the Monts Dore margins, e.g. the conspicuous «Grande Nappe » unit of previous authors, are here interpreted as stratigraphically beneath those exposed in proximal areas, and concealed in the central structural depression (caldera) demonstrated by previous gravimetric studies. The poorly constrained caldera should be envisioned as a compound, polygenic structure related to several ignimbrite eruptions spanning at least $350 \mathrm{ky}$., whose vent locations may have vary with time. The very scarce Fe-Mg silicate phases, biotite and amphibole, found in the pumices and ignimbrite matrix show complex compositional populations in most units which cannot be explained entirely by xenocrystic contamination and require further petrological investigations.
\end{abstract}

\title{
Composition et critères de corrélation des ignimbrites rhyolitiques du massif volcanique des Monts Dore (Massif central, France)
}

Mots-clés : ignimbrite, rhyolite, quartz, téphrostratigraphie, caldera, Massif central 
Résumé : Les unités pyroclastiques rhyolitiques, essentiellement des ignimbrites (dépôts d'écoulements de cendre et ponces) produites par des éruptions pliniennes appartenant à l'activité précoce (> 2,5 Ma) du massif volcanique plio-quaternaire des Monts Dore (Massif central français) sont revisitées, pour obtenir des données lithologiques et compositionnelles systématiques pouvant fournir une base rationnelle pour leur discrimination et leurs corrélations téphrostratigraphiques. Nous définissons ou redéfinissons et discriminons six unités pyroclastiques majeures (cinq ignimbrites et un dépôt de retombée ponceux), principalement sur la base de la texture des ponces et de l'assemblage minéral. Les ponces et les inclusions vitreuses dans les quartz montrent des compositions relativement homogènes de rhyolites riches en $\mathrm{SiO} 2$ avec de très faibles teneurs en $\mathrm{CaO}, \mathrm{MgO}$ et $\mathrm{FeO}$. Les assemblages minéraux sont feldspath alcalin \pm quartz \pm plagioclase + rares biotite \pm amphibole + phases accessoires (principalement sphène, zircon, oxydes, apatite). Les compositions des feldspaths, biotites et amphiboles se recouvrent largement d'une unité à l'autre et sont de faible utilité pour discriminer entre elles. Les données obtenues ont des implications concernant différentes questions volcanologiques encore débattues dans le massif des Monts Dore. Les principales unités pyroclastiques rhyolitiques reconnues aux marges du massif, notamment la «Grande Nappe » des auteurs antérieurs, sont considérées ici comme situées stratigraphiquement sous les ignimbrites affleurant dans la partie centrale, et donc piégées dans la dépression structurale (caldera) mise en évidence précédemment par des études gravimétriques. Cette caldera encore mal définie, doit être envisagée comme une structure composite et polygénique, formée par différentes éruptions ignimbritiques sur une période d'au moins 350000 ans, éruptions dont les évents ont pu varier au cours du temps. Les phases silicatées ferro-magnésiennes, biotite et amphibole, très peu abondantes dans les ponces et les matrices des ignimbrites, montrent des populations compositionnellement complexes dans la plupart des unités, qui ne peuvent s'expliquer entièrement par une contamination par xénocristaux et nécessitent des investigations pétrologiques complémentaires.

\section{Introduction}

The Massif central in France hosts a number of volcanic fields dated from the Miocene to the Holocene. Among these, the plio-quaternary Monts Dore (MD hereafter) volcanic complex provides the largest diversity of magma compositions and is distinctive in having erupted significant volumes of rhyolites (Fig. 1). The MD rhyolites have been emplaced 
mostly as ignimbrites (ash-and-pumice flow deposits) (Brousse, 1963 ; Brousse \& Lefèvre, 1966) with subsidiary volumes of lavas. Since the precise eruptive processes that lead to ignimbrite formation were not clearly envisioned at the time, the MD ignimbrites have been often referred to in the local literature as «nappes de ponces » (pumice sheets), a more descriptive locution. It was further proposed that the rhyolitic ignimbrite eruptions might have resulted in a large collapse caldera (Brousse, 1963 ; Brousse \& Lefèvre, 1966). General agreement since then has emerged on the presence of a concealed caldera («fosse volcanotectonique » of earlier authors) in the MD, mainly based on the evidence of a structural depression in the NW part of the volcanic field, in the vicinity of La Bourboule city (Fig. 1). The rhyolitic ignimbrites being among the oldest MD volcanic products, the morphological evidence for a caldera is poorly preserved, and this has led to varying proposals for the caldera size and outlines (Brousse, 1971 ; Vincent, 1980 ; Varet et al., 1980 ; Mossand et al., 1982).

The early workers acknowledged the interest of potentially extensive pyroclastic deposits such as the rhyolitic ignimbrites, for stratigraphic reconstructions of the MD volcanic complex (Brousse, 1963 ; Brousse \& Lefèvre, 1966). Several studies since then have adressed the characterization and correlation of the MD rhyolitic ignimbrites (e.g. Ménard, 1979 ; Ly, 1982 ; Pastre, 1987 ; Pastre \& Cantagrel, 2001). However, the criteria for distinguishing and correlating them remain currently confused and no firm stratigraphic scheme has emerged. This in turn restrains any reconstruction of the caldera structure. In this study, we adress this issue by providing a set of textural, mineralogical and compositional data aimed at fingerprinting the ignimbrite units and discriminating between them. We then discuss the ignimbrite stratigraphic relationships and their implications for the reconstruction of the inferred MD caldera. The compositional data provided here will also improve our knowledge of the MD rhyolitic magmatism, whose petrology has hitherto been mostly restricted to the lavas counterparts .

\section{Geological background}

The MD complex consists of dispersed vents and volcanic centers whose location is strongly controlled by regional fault tectonics. Only the Sancy volcano $(<1 \mathrm{Ma})$ is a centered major building of mostly intermediate (basic trachyandesites and trachyandesites) lavas that matches the volcanological features of a standard stratovolcano. The rest of the MD complex has been variously grouped into volcanic units or centers based on spatial, chronological or 
compositional criteria. The rhyolitic ignimbrites, according to available radiometric data, span a period from ca 3.2 to $2.75 \mathrm{Ma}$ (Nomade et al., 2014 and references herein) and are thus among the oldest MD volcanics, while some rhyolite lavas may be significantly younger (2.1-2.3 Ma for the Lusclade rhyolite, Cantagrel \& Baubron, 1983).

Among the MD rhyolitic ignimbrites, a conspicuous unit has long been recognized based on the very distinctive, strongly fibrous, texture of its pumices. This ignimbrite is discontinuously exposed mostly North and East of the MD, as far as ca $30 \mathrm{~km}$ from the central part of the MD, with apparent thicknesses up to $20 \mathrm{~m}$ (Rochefort quarry). Being the most extensive and voluminous $(5-10 \mathrm{~km} 3)$, it has been coined in the local literature as the «Grande Nappe» («Great sheet») after Vincent (1979). A loosely defined caldera structure has been inferred from geophysical and geological arguments in the central part of the MD, whose collapse has been commonly linked to the eruption of the "Grande Nappe » ignimbrite, after Vincent (1980). More local rhyolitic pyroclastic units, i.e. a $75 \mathrm{~cm}$ thick pumice fallout layer and an ignimbrite, have been described beneath the "Grande Nappe » in the Perrier section, $30 \mathrm{~km}$ East of the MD (Ly, 1982; Pastre \& Cantagrel, 2001). All the above units are considered as extra-caldera facies. Two additional rhyolitic ignimbrites have been described by Menard (1979) in the vicinity of La Bourboule city, referred to respectively as the «Nappe infrabasale» and «Nappe inférieure», which would be intra-caldera facies. The stratigraphic correlations between the intra- and extra-caldera units remain obscure and somewhat confusing, and will be discussed in this paper.

\section{Approach and methods}

Ignimbrite correlation is a common volcanological task in large-scale ignimbrite and caldera fields worldwide. Common criteria used for ignimbrite discrimination and correlation may include ignimbrite texture and structure at the field scale (lithofacies: degrees of compaction, welding, vapor-phase sintering,...), pumice texture, mineral assemblage and proportions, pumice whole-rock, glass and mineral compositions. A combination of criteria is generally required, as each of them has inherent limitations and potential pitfalls. Ignimbrite lithofacies may vary widely both vertically and laterally even within a single depositional unit. Pumice vesicularities and bubble shapes may vary along the course of an eruption depending on the conduit dynamics. Pumice compositions and phenocryst contents may also vary both vertically and laterally. Such variations are commonly encountered in large-volume ignimbrites, reflecting the tapping by the eruption of various storage regions of the magma 
reservoir. The MD ignimbrites are each of small volume (<10 km3) compared to most documented ash flow tuffs worldwide. However, compositional heterogeneities can also occur in small-volume eruptions if the magma reservoir is itself of small size. Compositional heterogeneities might also result from magma mixing/mingling effects. This is to be considered here since petrological evidence of magma mingling has been reported in the Lusclade rhyolite (Gourgaud \& Vincent, 1980).

In this study we examine lithofacies, pumice texture, mineral assemblage, and pumice, mineral, and glass inclusions compositions, to define and discriminate ignimbrite units as potential markers for further tephrostratigraphic correlations. The ignimbrite facies under study are nowhere welded nor even compacted ; they are almost loose or slightly indurated by argillic alteration, with few local facies being hydrothermally sintered by mostly zeolites. Two of the ignimbrites defined here are loose enough at least locally so that pumices (juvenile magma) of lapilli size can be sampled separately. This allows whole-rock composition analysis and gives better confidence on the juvenile character of the mineral assemblage. In all other units, only the whole ignimbrite material was sampled, which may include variable proportions of xenolithic (basement-derived) components. This implies that xenocrysts may contribute to various amounts the crystal assemblage retrieved from the ash $(<2 \mathrm{~mm})$ fraction.

Pumice lumps (when separated) and matrix samples have been gently crushed, slightly hand- sieved then washed in ultrasonic bath, before binocular observations. Free crystals in the sieve fractions $>250 \mu$ were hand picked and mounted in polished sections. Minerals and glass inclusions have been analysed by microprobe (EPMA) at ISTO with an acceleration voltage of $15 \mathrm{kV}$, counting time of $10 \mathrm{~s}$, and beam current of $6 \mathrm{nA}$ (glasses) or $10 \mathrm{nA}$ (crystals). The beam size was focused $(2 \mu \mathrm{m})$ for mineral phases, and enlarged to $5 \mu \mathrm{m}$ for glasses to minimize alkali migration. EPMA analytical errors are $1 \%$ for $\mathrm{SiO} 2, \mathrm{Al} 2 \mathrm{O} 3$ and $\mathrm{CaO}, 3 \%$ for $\mathrm{FeO}, \mathrm{MgO}$ and $\mathrm{TiO} 2,5 \%$ for $\mathrm{MnO}, \mathrm{Na} 2 \mathrm{O}$ and $\mathrm{K} 2 \mathrm{O}, 300$ ppm for $\mathrm{P} 2 \mathrm{O} 5$, and 700 ppm for $\mathrm{F}$. $\mathrm{Na} 2 \mathrm{O}$ loss is significant in glasses under the electron beam and tends to increase with increasing dissolved $\mathrm{H} 2 \mathrm{O}$ in the glass. To account for this, $\mathrm{Na} 2 \mathrm{O}$ in glass inclusions was corrected by linear regression using rhyolitic glass standards of varying water contents analyzed in the same microprobe session. Sets of several $\mathrm{cm}$-sized pumice lapilli for two units were analyzed for major elements by ICP-OES at CRPG Nancy.

\section{Results}




\subsection{Field observations, pumice textures and mineral assemblages}

Qualitative observations at the field and sample scales allow to define 6 main units among the MD rhyolitic ignimbrites. Our field survey of the MD field over the past 5 years suggests that these units are the most extensive and voluminous ones, while some minor units may also exist. The defined units are here named after reference localities, in order to overcome the problems encountered with previous nomenclatures based on inferred stratigraphic position, this being currently debatable.

The Rochefort-Sailles ignimbrite is the «Grande Nappe» of previous authors. This ignimbrite is a compound unit of several flow units with intercalated lapilli fallout layers (e.g. at Farges), whose basis is rarely exposed.

A Plinian fallout deposit in the Perrier section, ca $30 \mathrm{~km}$ East of the Monts Dore center, is a quartz-phyric massive, virtually ungraded layer $80 \mathrm{~cm}$ thick which, despite its remoteness from the MD center, relates to the MD activity based on petrological and stratigraphical evidence (Pastre \& Cantagrel, 2001). Given its thickness at such a distance from potential vent, this layer should be extensive around the Monts Dore yet it has so far been reported only at Perrier. This unit is referred to herein as the Perrier I fallout.

A $50 \mathrm{~cm}$ thick quartz-phyric ignimbrite recognized in the Perrier section (Ly, 1982) and referred to herein as the Perrier II ignimbrite, is lying above the Perrier I fallout (Pastre \& Cantagrel, 2001). A pebble bed of stream river sediment a few cm-thick separates the Perrier I and II layers, indicating that both deposits result from distinct eruptions, probably with a relatively short time span between them.

A moderately (diagenetically) indurated lithic-rich ignimbrite with small (mostly < $1 \mathrm{~cm}$ ) fibrous pumices, cropping out in the Fenestre settlement (at the South exit of La Bourboule city) and surroundings, is referred to herein as the Fenestre ignimbrite. Locally tens of meters thick, this is an aggredation of massive ungraded flow units with poorly distinguishable contacts. In its basal part, it consists of a set of stratified, finer grained, poorly sorted beds of surge-like character. According to its lithofacies and location, it corresponds to the «Nappe de ponces inférieure » of Ménard (1979). The matrix consists mostly of ash aggregates, which suggests deposition in a subaqueous (lacustrine) environment.

An almost loose, lithic-rich ignimbrite with distinctive white, poorly fibrous pumices, is exposed mainly on the western margin of La Bourboule city. This ignimbrite was not reported in previous works and is referred to herein as the Fohet ignimbrite.

A whitish argillic-altered, quartz-devoid ignimbrite almost lacking xenoliths is exposed in La Bourboule and its near vicinity. It is plastered against the granitic basement at 
the Roche des Fées hill and is named herein after this location. It corresponds to the « Nappe de ponces infrabasale » of Ménard (1979). In the MD geological literature, ignimbrites are generally considered rhyolitic when quartz-phyric, and accordingly this quartz-free ignimbrite has previously been classified as trachytic (Pastre \& Cantagrel, 2001 ; Nomade et al., 2014). However, some MD rhyolitic lavas are quartz-free, as examplified by the well known Lusclade rhyolite, indicating that quartz is not a systematic phenocryst phase in the MD magmas. The reasons why the Roche des Fées ignimbrite is ranked as a rhyolitic unit in this work are given in the result section.

\section{Intra-ignimbrite variations}

We first evaluated the intra-unit variability by comparing the ash matrix componentry at several locations for the most extensive ignimbrite, i.e. the Rochefort-Sailles ignimbrite (Table 1). Grain counting reveals very large variations of the lithic content from place to place. The amount of xenoliths is prone to vary greatly during the course of a plinian eruption, depending on conduit erosion, crater enlargement, and lithic recycling at the vent. The variations in lithic contents observed in the Rochefort-Sailles ignimbrite is likely due to our sampling of various eruptive and depositional units. Our field survey shows that at least three other ignimbrites (Fenestre, Fohet, Roche des Fées) are made of several depositional units, between which lithic variations can similarly be anticipated. The lithic content will thus not be considered a consistent feature for ignimbrite characterization and correlations in this study.

In the two ignimbrites from which pumice lapilli were sampled separately (RochefortSailles and Fohet), we have compared the vitric/crystal (V/C) proportions in the matrix ash and in the pumices. Our results (Table 1) clearly show that the ignimbrite matrix is in most cases strongly enriched in crystals compared to the pumices. This conforms with common observations from ignimbrites worldwide, this enrichment being classically explained by the preferential elutriation during pyroclastic flow emplacement of the ash vitric fraction relative to the crystal fraction, due to density contrast (Walker, 1972). The vitric/crystal fractionation may be more or less pronounced depending on transport distance and flow dynamics, so that the V/C ratio may vary greatly within a single ignimbrite. In this study we will not further consider the V/C ratio a reliable indicator for ignimbrite characterization and correlations.

\section{Inter-ignimbrite differences and ignimbrite fingerprinting}

Given the above mentioned limitations, the most reliable criteria for discrimination 
between the 6 rhyolitic pyroclastic units under study appear to be the pumice texture, the matrix crystal assemblage, and the matrix crystal proportions (Table 2). The combination of these criteria proves to be sufficient for discrimination purposes.

Pumices are distinctively highly fibrous and glassy, with conspicuous shiny vitreous breakage surfaces, in the Rochefort-Sailles ignimbrite. The Perrier I and II, Fohet and Fenestre ignimbrites contain both whitish dull and colorless translucent pumices, which reflects various degrees of glass alteration among the pumice fragments. Pumices are dominantly fibrous in the Fenestre and Fohet units, and dominantly spongy with subspherical bubbles in the Perrier I and II units. In the Roche des Fées ignimbrite, the pumice texture is largely oblitarated by glass alteration.

Mineral assemblage and proportions in the ignimbrite matrix have been observed under the binocular in the $500 \mu-1 \mathrm{~mm}$ and $250-500 \mu$ or $315-500 \mu$ sieve fractions. More or less broken, euhedral quartz where present and ubiquitous feldspar are by far the most abundant matrix minerals in all studied units. The relative abundance of quartz and feldspar is variable and is thought reliable as a fingerprinting criteria since fine elutriation during flow should not affect significantly the relative abundance of minerals of similar density like quartz and feldspar. The quartz/feldspar $(\mathrm{Q} / \mathrm{F})$ proportion is highest in the Perrier I and II units with $\mathrm{Q}>\mathrm{F}$, less in the Fenestre and Fohet units $(\mathrm{Q}<\mathrm{F})$ and still less in the Rochefort-Sailles ignimbrite $(\mathrm{Q}<<\mathrm{F})$, while quartz is absent in the Roche des Fées ignimbrite.

The abundance of heavy minerals $(d>2,86)$ and other accessory minerals in the ash matrix is very low in all units (a few percents of the whole crystals), though variable. In the $500 \mu-1 \mathrm{~mm}$ fraction of our samples, for instance, this amount seems to decrease in the order Rochefort-Sailles, Perrier (I and II), then the other ignimbrites. The Roche des Fées ignimbrite has such a very low content of Fe-Mg phases and in this respect is similar to the quartz-phyric ignimbrites and distinctive from typical MD trachytic ignimbrites.

The assemblage and relative proportions of heavy minerals differ significantly from an ignimbrite to another one (Table 2). The Perrier I and II units are distinctive by the higher relative abundance of sphene and to a lesser extent, zircon. The accessory assemblages of the Rochefort-Sailles and Fenestre ignimbrites are dominated by resorbed amphibole and biotite, followed in abundance by sphene and oxides. At the Rochefort site, amphibole is apparently absent in our sample. As the absence of amphibole at this site was already mentioned by previous authors (Besson, 1978 ; Ménard, 1979 ; Ly, 1982), it does not seem a sampling artifact and instead it likely reflects compositional differences between eruptive flow units within this compound ignimbrite. Biotite is dominant as an accessory phase and amphibole is 
lacking in the Roche des Fées and Fohet ignimbrites. Given the very low abundances of the heavy minerals, some phases could well be inherited from xenolithic lithologies and not be juvenile. For the Fohet and Rochefort-Sailles samples where the comparison can be made, the heavy minerals assemblages of separated crushed pumices are found to be similar to those of the ash matrix.This suggests that the mineral phases reported in Table 2 are likely to be all juvenile. The only exception is pyroxene that is absent in most units and in all known rhyolitic lavas from the MD, so that we suspect it is xenocrystic in the Perrier I and II units and it will not be further considered.

\subsection{Pumice and glass inclusion compositions}

Major element compositions of pumice fragments (whole rock) for 3 units (RochefortSailles, Perrier II and Fohet) are presented in Table 3 and Fig. 2, including available analyses from the literature. All pumice analyses have high water contents (3.5 to $6.5 \mathrm{wt} \%$ ) as a result of both residual dissolved water from the plinian eruptive dynamics and post-depositional alteration. Alteration may have modified oxides proportions, notably for the alkaline elements that need to be considered with caution. Nevertheless, the pumices have major-element compositions that are close to each other, being high-silica rhyolites with very low amounts of $\mathrm{CaO}(<0,5 \mathrm{wt} \%), \mathrm{MgO}(<0,25 \mathrm{wt} \%)$ and $\mathrm{FeO}(<1,25 \mathrm{wt} \%)$.

The MD rhyolitic quartz crystals have been subject to pioneering studies of glass inclusions (Clocchiatti, 1975; Massare, 1979) aimed at retrieving coexisting liquid compositions, dissolved water contents and entrapment temperatures. Here we provide an expanded data set of major-element compositions of quartz-hosted glass inclusions including four units (Table 3 and Fig. 2). The abundance and size of the glass inclusions differ from one unit to the other. Glass inclusions are less abundant and smaller on average in the Perrier and Rochefort-Sailles quartz crystals compared to the Fenestre and Fohet ones. Fracture cracks are more frequent in the Rochefort-Sailles and Fohet inclusions than in the Perrier and Fenestre ones. Analyses have been performed on inclusions devoid of fracture cracks in the observation plane. The glass inclusions from the different units largely overlap in composition and are slightly richer in $\mathrm{SiO} 2$ than the pumices. This does not seem to be an artifact due to silica enrichment of the glass inclusions, since glass inclusions and pumices plot on a similar trend in a $\mathrm{Al} 2 \mathrm{O} 3$ vs $\mathrm{SiO} 2$ diagram. The glass inclusions thus seem slightly more evolved than the pumices (whole juvenile magma). 
Despite potential inaccuracies in alkaline abundances, due to alteration in the pumices and to loss under analysis in the inclusions, compositions seem consistently richer in $\mathrm{K} 2 \mathrm{O}$ than in $\mathrm{Na} 2 \mathrm{O}$ with $\mathrm{Na} 2 \mathrm{O} / \mathrm{Na} 2 \mathrm{O}+\mathrm{K} 2 \mathrm{O}<0,5$ (Fig. 2). There is a general tendency of alkaline decrease with increasing $\mathrm{SiO} 2$ that reflects either feldspar fractionation toward the glass inclusion compositions or a cumulative effect of feldspar in the pumices. A stricking feature is the variability of the $\mathrm{K} 2 \mathrm{O} / \mathrm{Na} 2 \mathrm{O}$ ratio (à discuter avec Pich)

There are systematic although low amounts of normative corundum $(<2 \%)$ in all compositions. This may reflect alkali loss due to glass alteration in the pumices, and postdepositional alkali leakage in the glass inclusions. Such secondary effects are difficult to assess. However, that normative corundum is so systematic suggests a global tendency of the MD rhyolitic magmas toward a peraluminous character (à discuter avec Pich)

\subsection{Mineral compositions}

In this section we provide a comprehensive set of compositional data on the main silicate phases present in the MD rhyolitic ignimbrites, i.e. two feldspars, mica and amphibole. While feldspars are common phases, Fe-Mg phases are very scarce in all units as already mentioned and the number of analyses does not reflect their scarcity. In the Fohet and Rochefort-Sailles ignimbrites, analyzed minerals were extracted from pumices whereas in all other units, minerals were extracted from the ash matrix.

The Rochefort-Sailles, Fohet and Fenestre ignimbrites contain two feldspars whereas the Perrier I and II units and the Roche des Fées ignimbrite seemingly contain only K-feldspar (Fig. 3). K-feldspars are mostly sodic sanidine and anorthoclase (Or < 60). Some Or-rich sanidines found in the Perrier II ignimbrite are at odds with other compositions and considered xenocrysts. In the units where plagioclase is absent, the K-feldspars compositions tend to Na-richer $(\mathrm{Or}<50)$ than in the two-feldspars units. The Roche des Fées ignimbrite has distinctively Ca-richer K-feldspars on average. Plagioclase where present is Ca-poor, albite to oligoclase $\mathrm{An}<20$. That the Roche des Fées ignimbrite contains virtually no plagioclase strongly supports its interpretation as being rhyolitic rather than trachytic, since all known trachytic lavas in the MD contain plagioclase.

Biotites vary widely in composition (Table 4, Fig. 4). Apart from some compositions with high $\mathrm{Mg}^{*}(\mathrm{Mg} / \mathrm{Mg}+\mathrm{Fe})$ ratios analyzed in the Rochefort-Sailles pumices, all biotites plot as two discrete populations in terms of AlVI content. One has lower AlVI contents $(0,4-0,7)$ and a restricted range of $\mathrm{Mg}^{*}(0,55-0,65)$ values, while the other one has higher AlVI 
contents $(1-1,4)$ and a larger range of on average lower $\mathrm{Mg}^{*}$ values $(0,25-0,65)$. $\mathrm{TiO} 2$ and $\mathrm{MnO}$ contents are also highly variable. The low AlVI biotites have on average lower $\mathrm{TiO} 2$ and $\mathrm{MnO}$ contents than the high AlVI ones. In the Fohet pumices the biotites analyzed are all of the low AlVI type, while the Rochefort-Sailles biotites belong to the two types. The xenolith-poor Roche des Fées ignimbrite matrix also contain both types of biotites. This strongly suggests that both the low and high AlVI biotites are juvenile.

Amphiboles also have various compositions (Table 4, Fig. 5) that plot into two well distinct types, one with low AlIV contents $(0,5-0,9)$, the other one with much higher AlIV contents $(2,1-2,4)$. There is no systematic correlation between AlIV composition and the amphibole macroscopic coloration. The green and brown amphibles are of the low and high AlIV types, respectively, in the Fenestre and Rochefort-Sailles ignimbrites. The brown amphiboles of the Perrier I fallout are of the low AlIV type. In the Perrier II ignimbrites, analyzed green amphiboles are of the high AIIV type while brown ones are found of the two compositional types. The only amphiboles extracted from pumice material are from the Rochefort-Sailles ignimbrite and are of the green, low AlIV type. The low and high AlIV amphiboles span about the same large range of $\mathrm{Mg}^{*}$ ratios, slightly shifted toward larger $\mathrm{Mg}^{*}$ for the high AlIV type. The two green amphiboles recovered from the Perrier II ignimbrite have distinctively lower $\mathrm{Mg}^{*}$. Other elements $\mathrm{Na} 2 \mathrm{O}, \mathrm{K} 2 \mathrm{O}, \mathrm{TiO} 2$ and $\mathrm{MnO}$ vary consistently with the AlIV content, $\mathrm{Na} 2 \mathrm{O}, \mathrm{K} 2 \mathrm{O}$ and $\mathrm{TiO} 2$ being lower and $\mathrm{MnO}$ higher in the low AlIV amphiboles compared to the high AlIV ones. $\mathrm{MnO}$ and $\mathrm{Na} 2 \mathrm{O}$ are much more variable in the low AlIV amphiboles than in the high AlIV ones.

\section{Discussion}

\subsection{Ignimbrite fingerprinting and correlation criteria}

We define in this study 6 rhyolitic pyroclastic units (1 pumice fallout and 5 ignimbrites) that we consider likely the most voluminous in the MD, based either on their thickness in the central structural depression, or on their extent or remoteness in the MD marginal areas. We have documented for each unit textural and compositional features at reference sites (Fig. 1), that we summarize and discuss below in the perspective of discriminating between the ignimbrites on a rationalized basis and providing correlation criteria for further stratigraphic studies. The pumice whole-rock and the glass inclusion compositions show that the juvenile magmas of all units are close to each other, being high-silica rhyolites with very low $\mathrm{CaO}$, 
$\mathrm{MgO}$ and FeOt contents (Table 3). There is large inter-unit overlapping of the pumice compositions (based on 3 units) and of the glass inclusion compositions as well (based on a larger 5 units sampling) (Fig. 2). This does not give clues to discrimination between the pyroclastic units under study.

The shift towards higher $\mathrm{SiO} 2$ of the glass inclusions compared to the pumices is small (ranges $76-79 \%$ against $75-77,5 \%$ on a recalculated $100 \% \mathrm{H} 2 \mathrm{O}$-free basis, Fig. 2), suggesting that the ignimbrite-generating rhyolitic magmas are almost liquids and should be poorly phyric, which is directly shown by the low crystal/vitric ratio observed in crushed pumices (Table 1). The low expected phenocryst proportion and the low $\mathrm{FeO}$ and $\mathrm{MgO}$ contents in the rhyolitic magmas should result in very low abundances of Fe-Mg silicate phases. This is verified by our observations in the crushed pumices from the Rochefort-Sailles and Fohet ignimbrites ( $<5 \%$ of the phenocrysts population, $<<1 \%$ of the whole magma) and in the ignimbrite ash matrix of all units.

Given the very scarcity of the Fe-Mg silicates in the rhyolitic magmas under study, the contamination by xenocrystic Fe-Mg phases in the ignimbrite matrix might be significant, which means that the «heavy minerals » assemblage recovered in the ash matrix samples should be considered with caution. Quantitative assessment of the heavy minerals proportions and their use as inter-ignimbrite discriminators (e.g. Pastre, 1987 ; Pastre \& Cantagrel, 2001) can be biased by (1) sampling representativity due to their overall paucity, (2) intra-ignimbrite variability among different eruptive/depositional units, and (3) variability due to particle density fractionation during pyroclastic flow transport (cf. section 4.1). However, some interignimbrite differences we observe in the heavy minerals assemblages seem to be reliable on a qualitative basis. The Perrier I and II units are distinctively dominated by sphene and zircon over the Fe-Mg silicates. The Fohet and Roche des Fées ignimbrites are strongly dominated by biotite, amphibole being absent or virtually so, in contrast with the 4 other units where amphibole and biotite coexist.

The mineral compositions afford rather little help for discrimination between the ignimbrites. Biotites and amphiboles each consist of two distinctive compositional subpopulations that are both present in most units (Figs $4 \& 5$ ). In every subpopulation there is large overlap of the compositions in the different units. The feldspar compositions allow to distinguish two groups, K-feldspar bearing (Perrier I and II, Roche des Fées) and twofeldspars bearing (Rochefort-Sailles, Fenestre, Fohet) units. Plagioclase and K-feldspar compositions show no significant inter-ignimbrite differences, except the Ca-richer tendency in the Roche des Fées K-feldspars (Fig. 3). While the quartz-hosted glass inclusions have 
compositions that do not separate the ignimbrites, their average size and relative abundance seem significantly variable from one unit to another one. Such systematic differences of glass inclusion features have already been reported between the « Nappe supérieure » (RochefortSailles ignimbrite herein) and « Nappe inférieure » (Fenestre ignimbrite herein) (Clocchiatti, 1975 ; Massare, 1979). Investigation of mineral compositions and glass inclusions requires laboratory techniques and efforts and cannot be used routinely for ignimbrite correlation purposes. As a result of our investigations, the most significant and most easyly handled criteria for discriminating the MD rhyolitic ignimbrites are the pumice texture and the quartz/feldspar proportion, along with, to a lesser degree, the heavy minerals assemblage. Combining those criteria allows to identify and distinguish the six units under study here, at least from the reference samples we used. We stress, however, that intra-unit variability must be anticipated and could obscure the discrimination criteria. This should be tested first by sampling stratigraphic sections where several eruptive/depositional units of a single ignimbrite are exposed without hiatus, which was beyond the scope of this work.

\subsection{Ignimbrite stratigraphy}

In the MD external area, the relative stratigraphy of the Perrier I fallout, Perrier II ignimbrite, and Rochefort-Sailles ignimbrite, from base to top, has already been established in the Perrier section (Ly, 1982; Pastre \& Cantagrel, 2001). In the central depression, the relative stratigraphical position of the Roche des Fées and Fenestre ignimbrites has been recognized by Ménard (1979). The correlations between the external and internal units are more challenging and has led to conflicting proposals in the literature.

Earlier authors (Brousse, 1963 ; Bellon et al., 1972 ; Ménard, 1979) considered the ignimbrites exposed in the central area (their «nappe infrabasale » and «nappe inférieure ») as stratigraphically beneath the Rochefort-Sailles ignimbrite (part of their «Nappe supérieure »). We do not follow this interpretation. The similar magma compositions of the external and internal ignimbrites, as revealed by pumices and glass inclusions compositions, suggest that they all were tapped from the same magma reservoir beneath the central part of the MD complex. This in turn suggests that the external ignimbrites vented from the same area as the internal ignimbrites. Given this and the large volume anticipated for the external units, notably the Rochefort-Sailles ignimbrite, these should be observable in the central depression if younger. Instead, in the central area the external units are nowhere exposed intervening between the internal ignimbrites and the various younger volcanics overlying 
them.

Differently from the aforementioned authors, Vincent $(1979,1980)$ and Mossand et al. (1982) correlated the Rochefort-Sailles ignimbrite with all internal ignimbrites, the whole forming their «Grande Nappe». Brousse et al. (1989) and Pastre \& Cantagrel (2001) correlated the external Rochefort-Sailles ignimbrite with internal ignimbrite facies we define as the Fenestre ignimbrite. This lateral correlation between the "Grande Nappe » and the internal ignimbrites, and specifically the Fenestre ignimbrite, is not supported by our data. These provide sufficient evidence that the Rochefort-Sailles and Fenestre ignimbrites are distinct stratigraphic units. Although they show some similarities (eg. the feldspar compositions and the biotite-amphibole assemblage), they differ markedly in terms of pumice texture and to a lesser degree in quartz/feldspar proportion. Their distinctive quartz-hosted glass inclusion populations, as already recognized by Clocchiatti (1975), might also be used as discriminating evidence. Minor discrepancies in mica populations (the Fenestre ignimbrite apparently lacks the high AlVI subpopulation, fig. 4) and in green amphibole compositions (fig. 5) may be given as additional, although poor evidence.

The only way to concile our data and the geological observations is in our opinion, to consider the units exposed in the external areas as older than the internal ignimbrites, concealed beneath the latter in the central area. Our assumption is consistent with the following independant evidence :

(1) geophysical surveys have revealed a gravimetric anomaly in the central area of the MD complex (Fig. 1) that suggests filling of a morphological or structural depression by low density sedimentary or volcaniclastic facies, confirmed by exploratory drillings down to over one hundred meters (Varet et al., 1980 ; Mossand et al., 1982). If looking for material prone to fill this structure, the ignimbrites found externally and not exposed in the central area are good candidates.

(2) some lacustrine sediments stratigraphically beneath the Fenestre ignimbrite in the Vendeix valley contain euhedral, often unbroken, volcanic quartz that must be derived from an older quartz-bearing pyroclastic material. Since the Roche des Fées ignimbrite underlying the Fenestre one is quartz-devoid, the Perrier and Rochefort-Sailles pyroclastic units are candidate facies for the origin of the lacustrine quartz.

(3) radiometric Ar-Ar data recently obtained on the internal ignimbrites (Nomade et al., 2014) give ages significantly younger than those previously published for the Perrier and RochefortMontagne units (Féraud et al., 1990 ; Duffell, 1999 ; Nomade et al., 2013).

Our stratigraphic reconstruction is summarized in Fig. 6. Available Ar-Ar ages suggest 
that the 3 external units Perrier I, II and Rochefort-Sailles were erupted within a short time span of less than 50,000 years, in agreement with field relationships in the Perrier section. A much longer gap of ca 0.15 m.y. gap separates the Roche des Fées ignimbrite from the older external units. A time interval of ca 0.10 m.y. then separates the Roche des Fées and Fenestre ignimbrites, marked by lacustrine sedimentation in the central area. In our stratigraphic reconstruction, the position of the Fohet ignimbrite remains undefined, since no contact between the Fohet ignimbrite and the two other internal ignimbrites has yet been observed. Given the exposure continuity between the Roche des Fées and Fenestre ignimbrites in the Vendeix valley, the Fohet ignimbrite should stratigraphically occur either beneath the Roche des Fées ignimbrite or above the Fenestre one.

\subsection{Volcanological and petrological issues}

The current view hitherto has been that the MD caldera formed in response to a single major ignimbrite-forming eruption corresponding to the Rochefort-Sailles ignimbrite («Grande Nappe», Vincent, 1979; Varet et al., 1980; Mossand et al., 1982). This interpretation followed in part from the assignment of most of the internal ignimbrites to the «Grande Nappe », which gave it a much larger volume than any other pyroclastic unit. The recognition that the internal ignimbrites are distinct from and younger than the "Grande Nappe », and that at least six major rhyolitic pyroclastic units spanning more than 0.3 m.y. were erupted from the central area of the Monts Dore, allows a reappraisal of the simple earlier view. It is still unclear whether the proposed caldera (Mossand et al., 1982 ; Fig. 1) is the result of volcanic collapse processes only as envisioned by the aforementioned authors, or partly of tectonic subsidence. To the degree it is a volcanic collapse structure, however, we contend it should be better envisioned as a polygenic, compound structure, resulting from a number of explosive eruptions whose vents may have shifted and possibly coalesced with time. The proposed caldera is in our opinion unrealistically large (ca $6 \times 5 \mathrm{~km}$ ) with regard to the estimated volume of the «Grande Nappe » $(<10 \mathrm{~km} 3)$. If the poorly constrained caldera outlines were confirmed, they would better fit with an incremental structure formed through repeated ignimbrite-forming eruptions. In our view, the area corresponding to the minimal isogal (-30 mgals, Fig. 1), if it reflects the deepest parts of the depression, is likely to be the area where the earliest pyroclastic units, including the «Grande Nappe », are the thickest, and to be their source area.

Our revised stratigraphy also implies revisions of the chronology of the massive lavas 
exposed in the central depression relative to the ignimbrites. The age of the caldera was previously estimated around 2.5 Ma (based on the presumed age of the «Grande Nappe » at the time), and volcanics older than 2.5 Ma were considered as pre-caldera (Mossand et al., 1982). The exposure of pre-caldera volcanics at the same structural level as the syn-caldera ignimbrites in the central area implied that the caldera had undergone some post-collapse resurgence. In our interpretation, starting the caldera history before $3 \mathrm{Ma}$ and considering an ignimbrite activity over a time interval of at least $0.3 \mathrm{~m} . \mathrm{y}$. leaves much time for the emplacement of various volcaniclastics and lavas during the caldera incremental development. With respect to the early caldera related to the Perrier and Rochefort-Sailles units, the pre-caldera lavas of Mossand et al. (1982) are clearly post-caldera, and no resurgence is required during the evolution of the whole caldera complex.

Complex mineral compositions found in the ignimbrites, notably for micas and amphiboles, raise questions regarding the petrological significance of those compositions. The mica and amphibole population in most units is a mix of two well distinct subpopulations that cannot be both in equilibrium with the rhyolitic magmas represented by the ignimbrite pumices and the glass inclusions. Deciphering the status of each subpopulation as phenocrystic, antecrystic or xenocrystic might provide clues to the differentiation processes and conditions in the magma chamber tapped by the rhyolitic magmas. This is not straightforward, as we note that two subpopulations are frequently found in pumices (Rochefort-Sailles and Fohet) and in the matrix of xenolith-poor units (Perrier I and Roche des Fées) where they are a priori considered juvenile. A detailed treatment of this issue requires additional investigations, including the few MD rhyolitic lavas of the same period, which is being adressed by ongoing studies.

\section{Acknowledgments}

We thank ISTO staff members I. Di Carlo for assistance in EPMA analyses and SEM, J.-G. Badin and S. Janiec for thin and polished sections, P. Joliot for ignimbrite sample preparation. Master students at Orléans Univ. M. Drouillet, A.F. Kunzelmann and G. Dreux helped in data acquisition and processing. JLB and LA thank Master students from Orléans Univ. for sharing field work in the Monts Dore over the last 5 years. This work was partly funded by TLS company. 


\section{REFERENCES}

Bellon H, Brousse R, Mervoyer B, Blais S (1972) Age absolu du massif du Mont-Dore. C R Acad Sci Paris 274:2740-2743

Besson JC (1978) Les formations volcaniques du versant oriental du massif du Mont-Dore (Massif Central français), feuille 1/25 000 Veyre- Monton 5-6. Thèse $3^{\circ}$ cycle, Clermont Ferrand Univ., pp. 167.

Brousse R., 1963. Identification de deux « coulées de ponces » dans le massif volcanique du Mont-Dore. CR Acad. Sc. Paris, D 257, 2869-2871.

BROUSSE R.and LEFEVRE, C., 1966, Nappes de ponces du Cantal et du Mont-Dore. Leurs aspects volcanologique, pétrographique et minéralogique. Bull. Soc. géol. France, 7, 8, p. 223-245.

Brousse R. (1971) - Magmatologie du volcanisme néogène et quaternaire du Massif Central. In : Symposium « Géologie, géomorphologie et structure profonde du Massif Central français », Clermont-Ferrand, Plein Air Service Ed., 377-478.

Brousse R., Tempier P., Rançon J.P., Veyret-Metjian Y., 1989. Feuille 1/50000 Bourg-Lastic (716). Notice explicative. BRGM, pp. 78.

Cantagrel JM, Baubron JC (1983) Chronologie des éruptions dans le massif volcanique des Monts Dore (Méthode potassium-argon). Implications volcanologiques. Géol Fr, I, 1- 2:123142

Clocchiatti, 1975. Les inclusions vitreuses des cristaux de quartz. Etude optique, thermooptique et chimique. Applications géologiques. Mem. Soc. Géol. Fr., 54, 122, pp. 96

Duffell A (1999) Contribution géochronologique à la stratigraphie volcanique du Massif des Monts Dore par la méthode 40Ar/39Ar. Master dissertation, Clermont-Ferrand Univ.

Féraud G, Lo Bello P, Hall CM, Cantagrel JM, York D, Bernat M (1990) Direct dating of Plio-Quaternary pumices by 40Ar/39Ar step- heating and single-grain laser fusion methods: the example of the Monts-Dore massif (Massif Central, France). J Volcanol Geotherm Res 40:39-53. doi:10.1016/0377-0273(90)90105-O

GOURGAUD, A. and VINCENT, P.M, 1980, Coexistence de magmas rhyolitique et trachyandésitique au dôme de la Gacherie (Monts Dore, Massif Central français). Implications génétiques. C.R. Acad. Sci. Paris D290, p. 81-84.

Ly M.H. (1982) Le Plateau de Perrier et la Limagne du Sud: Etudes volcanologiques et géochronologiques des produits montdoriens (Massif central français). Ph.D Dissertation, Clermont Ferrand Univ., pp. 180.

Massare, 1979. Etude des inclusions vitreuses de quelques minéraux de roches volcaniques acides : thermométrie, barométrie, compositions chimiques et éléments volatils dissous. $\mathrm{PhD}$ thesis , Paris VI Univ., pp. 179. 
Ménard JJ (1979) Contribution à l'étude pétrogénétique des nappes de ponces du massif volcanique du Mont-Dore (Massif Central français). PhD dissertation, Paris 11 Orsay Univ., pp. 105.

Mossand P (1983) Le volcanisme ante et syn-caldera des Monts Dore (Massif central français). Implications géothermiques. PhD dissertation, Clermont-Ferrand Univ., pp. 197.

Mossand P, Cantagrel JM, Vincent PM (1982) La caldera de Haute-Dordogne. Age et limites (Massif des Monts- Dore, France). Bull Soc Geol Fr 7, 24:727-738

Nomade S, Pastre JF, Guillou H, Faure M, Guérin G, Delson E, Debard E, Voinchet P, Messager E (2013) 40Ar/39Ar constraints on some French landmark Late Pliocene to Early Pleistocene large mammalian paleofauna: paleoenvironmental and paleoecological implications. Quat Geochronol. doi:10.1016/j.quageo.2012.12.006

Nomade S., PASTRE J.F., NEHLIG P., Guillou H., Scao V., SCAILLET S., 2014. Tephrochronology of the Mont-Dore volcanic Massif (Massif Central, France) : new 40Ar/39Ar constraints on the Late Pliocene and Early Pleistocene activity. Bull. Volanol., 76:798 doi : 10.1007/s00445-014-0798-6

Pastre JF (1987) Les formations plio-quaternaires du bassin de l'Allier et le volcanisme régional ( Massif Central, France). Rapports géodynamiques, corrélations téphrochronologiques, implications. PhD dissertation, Paris VI Univ., pp. 733.

Pastre JF, Cantagrel JM (2001) Téphrostratigraphie du Mont Dore (Massif Central, France). Quaternaire 12(4):249-267

Varet J., STIELTJES L., GERARD A., FOUILLAC C., 1980. Prospection géothermique intégrée dans le massif du Mont-Dore. Advances in European Geothermal Research, Strasbourg \& BRGM File 80 SGN 150 GTH.

Vincent PM (1979) Un repère chronologique dans la caldéra des Monts Dore (Massif Central français) : les pyroclastites du dôme de la Gacherie. C R Acad Sci Paris, 289:1009-1012

Vincent PM (1980) Volcanisme et chambres magmatiques: 1'exemple des monts Dore. Mém hors-série Soc géol Fr 10:71-85

Walker GPL 1972. Crystal Concentration in Ignimbrites. Contrib. Mineral. Petrol., 36, 135146.

\section{Table captions}

Table 1: Component proportions of MD ignimbrites based on grain counting in selected sieve fractions. Counting on random sets of 200-250 grains per sample. Two ignimbrite stratigraphic units are considered, the Rochefort-Sailles and the Fohet ignimbrites (see text). For the Rochefort-Sailles ignimbrites, different sampling locations (thus possibly different eruptive and depositional units) are compared (see Fig. 1 for location). Matrix refers to the 
ignimbrite ash matrix, with Vitric (juvenile) - Lithic (xenolithic) - Crystal (mostly juvenile, potentially variable xenocrystic contribution) proportions expressed as $\%$ on a $\mathrm{V}+\mathrm{C}+\mathrm{L}=100$ basis. Pumice refers to gently crushed sets of juvenile pumice lapilli. C (crystal) / V (vitric) + $\mathrm{C}$ expressed as $\%$ on a $\mathrm{V}+\mathrm{C}=100$ basis.

Table 2: Characteristic features and discriminating criteria of the MD ignimbrites under study. $\mathrm{C}=$ Crystals, $\mathrm{P}=$ Pumice (vitric), $\mathrm{Q}=$ Quartz, $\mathrm{F}=$ Feldspar. Mineral assemblages listed here are from the ash matrix for all units. Accessory minerals are loosely listed in decreasing order of abundance. All mineral phases in trivial amount and of obvious accidental origin (inherited from metamorphic or mafic lithologies) are omited.

Table 3: Major-element compositions and CIPW norm of the pumice component (juvenile whole-rock) and of glass inclusions in quartz from MD rhyolitic ignimbrites. The data set for pumices includes previous analyses from the literature and 3 new analyses. Samples from several locations give internal variability of the Rochefort-Sailles ignimbrite. The glass inclusion compositions are average values of 5 to 12 inclusions depending on the unit (inclusion number in brackets). Nine major oxides are recalculated on a 100\% sum. Pumice $\mathrm{H} 2 \mathrm{O}$ contents are given from the original analyses. Fe is recalculated as $\mathrm{FeO}$ total. The CIPW norm is calculated assuming a normalized $\mathrm{Fe} 3+/ \mathrm{Fe} 2+$ ratio of 0.15 .

Table 4: Representative compositions of biotites and amphiboles from MD rhyolitic ignimbrites. All analyses from this work.

\section{Figure captions}

Fig. 1: Simplified geological map of the Monts Dore volcanic complex with locations of reference samples of the rhyolitic pyroclastics under study. MD for Monts Dore in legend. Bouguer anomaly isogals $-30,-25$ and -20 mgals in the MD central structural depression from Varet et al. (1980). Outline of the caldera as proposed by Mossand et al. (1982).

Fig. 2: $\mathrm{Na} 2 \mathrm{O}+\mathrm{K} 2 \mathrm{O}$ vs $\mathrm{SiO} 2$ and $\mathrm{Na} 2 \mathrm{O} / \mathrm{Na} 2 \mathrm{O}+\mathrm{K} 2 \mathrm{O}$ vs $\mathrm{SiO} 2$ diagrams for pumice and quartz-hosted glass inclusion compositions from the MD rhyolitic ignimbrites. Data for 
pumice samples as in Table 3. For glass inclusions, each symbol represents one inclusion, whose composition is averaged from 1 to 3 spot analyses.

Fig. 3: Feldspar compositions of the MD rhyolitic ignimbrites in the anorthite-albiteorthoclase (An-Ab-Or) triangle. Labels are molar percentages of Or and An. Data from this work for all units, with previous data from Menard (1979) for the Fenestre ignimbrite. Analyzed crystals are from separated pumices in the Fohet and Rochefort-Sailles ignimbrites, from the matrix in all other units. One analysis per (core) crystal.

Fig. 4: Biotite compositions of the MD rhyolitic ignimbrites shown in $\mathrm{Al}^{\mathrm{VI}}$ vs $\mathrm{XMg}$ and $\mathrm{TiO} 2$ vs $\mathrm{Al}^{\mathrm{VI}}$ diagrams. Data from this work with two additional analyses from Menard (1979) for the Fenestre ignimbrite. Analyzed crystals are from separated pumices for the Fohet ignimbrite, from both separated pumice and matrix for the Rochefort-Sailles ignimbrite, and from matrix for all other units. One analysis per (core) crystal.

Fig. 5: Amphibole compositions of the MD rhyolitic ignimbrites shown in $\mathrm{Al}^{\mathrm{IV}}$ vs $\mathrm{XMg}$ and $\mathrm{MnO}$ vs XMg diagrams. Data from this work for all units, with previous data from Besson (1978) and Menard (1979) for the Fenestre and Rochefort-Sailles ignimbrites. Analyzed crystals are from both separated pumices and matrix for the Rochefort-Sailles ignimbrite, from matrix for all other units. One analysis per (core) crystal.

Fig. 6: Schematic stratigraphic scheme of the MD major rhyolitic ignimbrites. Stratigraphic relationships as observed in the Perrier section and on the right side of the Vendeix valley, South of La Bourboule (note the different vertical scales). In the Perrier section, the Perrier 1 fallout layer, Perrier II ignimbrite and Rochefort-Sailles ignimbrite are separated by river pebble deposits. In the Vendeix section, lacustrine sediments underlie the Roche des Fées ignimbrite and separate this unit from the Fenestre ignimbrite. Inferred relationships between the Perrier (external) and Vendeix (internal) units from indirect evidence discussed in text. The Fohet ignimbrite has a yet undefined stratigraphic position, either beneath the Roche des Fées ignimbrite or on top of the Fenestre ignimbrite. Available Ar-Ar ages are given in Ma with uncertainties quoted at $1 \sigma$, from the following references: (1) Duffell (1999), (2) Nomade et al. (2013), (3) Féraud et al. (1990), and (4) Nomade et al. (2014). 


\begin{tabular}{|c|c|c|c|c|c|c|}
\hline & \multirow[b]{2}{*}{ sieve fraction } & \multicolumn{3}{|c|}{ Matrix } & & \multirow{2}{*}{$\frac{\text { Pumice }}{C / C+V \%}$} \\
\hline & & Vitric \% & Crystal \% & Lithic \% & $C / C+V \%$ & \\
\hline \multicolumn{7}{|l|}{ Rochefort-Sailles ign. } \\
\hline \multirow[t]{3}{*}{ Rochefort } & $2 \mathrm{~mm}-1 \mathrm{~mm}$ & 70 & 14 & 16 & 17 & \\
\hline & $1 \mathrm{~mm}-500 \mu$ & 67 & 20 & 13 & 23 & 0,6 \\
\hline & $500 \mu-315 \mu$ & 87 & 7 & 6 & 7 & 0,04 \\
\hline \multirow[t]{3}{*}{ Sailles } & $2 \mathrm{~mm}-1 \mathrm{~mm}$ & 74 & 7 & 19 & 8 & \\
\hline & $1 \mathrm{~mm}-500 \mu$ & 84 & 9 & 7 & 10 & 0,7 \\
\hline & $500 \mu-315 \mu$ & 87 & 6 & 7 & 6 & \\
\hline \multirow[t]{3}{*}{ Mareuges } & $2 \mathrm{~mm}-1 \mathrm{~mm}$ & 69 & 9 & 22 & 12 & \\
\hline & $1 \mathrm{~mm}-500 \mu$ & 9 & 35 & 56 & 80 & 1,4 \\
\hline & $500 \mu-315 \mu$ & & & & & 0,7 \\
\hline \multirow[t]{3}{*}{ Le Barry } & $2 \mathrm{~mm}-1 \mathrm{~mm}$ & 58 & 4 & 35 & 7 & 3 \\
\hline & $1 \mathrm{~mm}-500 \mu$ & 77 & 9 & 14 & 10 & 1,7 \\
\hline & $500 \mu-315 \mu$ & & & & & 0,6 \\
\hline \multirow[t]{2}{*}{ Perrier } & $2 \mathrm{~mm}-1 \mathrm{~mm}$ & 91 & 1 & 8 & 1 & \\
\hline & $1 \mathrm{~mm}-500 \mu$ & 98 & 1 & 1 & 1 & \\
\hline \multirow[t]{3}{*}{ Fohet ign. } & $2 \mathrm{~mm}-1 \mathrm{~mm}$ & 75 & 9 & 16 & 11 & 8 \\
\hline & $1 \mathrm{~mm}-500 \mu$ & 80 & 3 & 17 & 3 & 3 \\
\hline & $500 \mu-315 \mu$ & 57 & 32 & 11 & 36 & 3 \\
\hline
\end{tabular}

Table 1 


\begin{tabular}{|c|c|c|c|}
\hline unit & Pumice texture & Main minerals & Accessory minerals \\
\hline Perrier I & $\begin{array}{l}\text { mainly spongy } \\
\text { very phyric }\end{array}$ & $\begin{array}{l}\mathrm{C}>\mathrm{P} \\
\mathrm{Q}>\mathrm{F}\end{array}$ & $\begin{array}{l}\text { Sphene } \\
\text { Zircon } \\
\text { Oxides } \\
\text { Brown Pyroxene } \\
\text { Brown \& Green Am } \\
\text { Biotite } \\
\text { Apatite }\end{array}$ \\
\hline Perrier II & $\begin{array}{l}\text { mainly spongy } \\
\text { very phyric }\end{array}$ & $\begin{array}{l}C>P \\
Q>F\end{array}$ & $\begin{array}{l}\text { Sphene } \\
\text { Zircon } \\
\text { Oxides } \\
\text { Brown \& Green Am } \\
\text { Green Pyroxene } \\
\text { Biotite } \\
\text { Apatite } \\
\end{array}$ \\
\hline Rochefort-Sailles & $\begin{array}{l}\text { strongly fibrous } \\
\text { almost aphyric }\end{array}$ & $\begin{array}{l}\mathrm{C}<\mathrm{P} \\
\mathrm{Q}<\mathrm{F}\end{array}$ & $\begin{array}{l}\text { Green \& Brown Am } \\
\text { Sphene } \\
\text { Zircon } \\
\text { Biotite } \\
\text { Pyroxene } \\
\text { Oxides } \\
\end{array}$ \\
\hline Fohet & $\begin{array}{l}\text { fibrous to spongy } \\
\text { phyric }\end{array}$ & $\begin{array}{l}\mathrm{C}<\mathrm{P} \\
\mathrm{Q}<\mathrm{F}\end{array}$ & $\begin{array}{l}\text { Biotite } \\
\text { Sphene } \\
\text { Oxides } \\
\text { Zircon } \\
\end{array}$ \\
\hline Fenestre & $\begin{array}{l}\text { fibrous to spongy } \\
\text { phyric }\end{array}$ & $\begin{array}{l}\mathrm{C}<\mathrm{P} \\
\mathrm{Q} \sim \mathrm{F}\end{array}$ & $\begin{array}{l}\text { Green \& Brown Am } \\
\text { Biotite } \\
\text { Oxides } \\
\text { Sphene } \\
\text { Zircon }\end{array}$ \\
\hline Roche des Fées & $\begin{array}{l}\text { altered pumice } \\
\text { phyric }\end{array}$ & $\begin{array}{l}\mathrm{C}<\mathrm{P} \\
\mathrm{Q} \text { absent }\end{array}$ & $\begin{array}{l}\text { Biotite } \\
\text { Apatite } \\
\text { Sphene } \\
\text { Zircon } \\
\text { Oxides } \\
\end{array}$ \\
\hline
\end{tabular}

Table 2 


\begin{tabular}{|c|c|c|c|c|c|c|c|c|c|c|c|c|c|}
\hline \multirow{5}{*}{$\begin{array}{c}\text { unit } \\
\text { locality } \\
\text { sample } \\
\text { reference }\end{array}$} & \multicolumn{8}{|l|}{ Pumice } & & \multicolumn{4}{|l|}{ Glass inclusions } \\
\hline & Fohet & Perrier II & Rochefort-Sailles & Rochefort-Sailles & Rochefort-Sailles & Rochefort-Sailles & Rochefort-Sailles & Rochefort-Sailles & Rochefort-Sailles & Fohet & Perrier I & Rochefort-Sailles & Fenestre \\
\hline & & & Le Barry & Mareuge & Mareuge & Douharesse & Sailles & Sailles & Les Arnats & & & Sailles & \\
\hline & MD12-1 P & & MD11-7 P & MD11-9 P & & & & & & MD10-16 (10) & MD10-5 (5) & MD10-14 (5) & MD10-19 (12) \\
\hline & this work & Ly 1982 & this work & this work & Mnard 1979 & Brousse 1961 & Ly 1982 & Ly 1982 & Ly 1982 & this work & this work & this work & this work \\
\hline SiO2 & 77,68 & 74,69 & 76,66 & 75,69 & 75,04 & 75,64 & 77,16 & 76,07 & 77,46 & 77,84 & 77,29 & 77,18 & 77,97 \\
\hline TiO2 & 0,11 & 0,08 & 0,09 & 0,13 & 0,08 & 0,11 & 0,05 & 0,31 & 0,42 & 0,09 & 0,07 & 0,08 & 0,08 \\
\hline $\mathrm{Al} 2 \mathrm{O} 3$ & 12,57 & 13,69 & 13,02 & 13,82 & 13,57 & 13,98 & 12,98 & 13,32 & 12,79 & 12,31 & 12,50 & 12,37 & 12,29 \\
\hline FeOt & 0,88 & 1,21 & 0,81 & 1,05 & 1,21 & 1,11 & 0,93 & 0,94 & 0,75 & 0,64 & 0,71 & 0,76 & 0,64 \\
\hline MnO & 0,10 & 0,19 & 0,11 & 0,10 & 0,01 & 0,11 & 0,15 & 0,09 & 0,09 & 0,07 & 0,26 & 0,08 & 0,11 \\
\hline MgO & 0,06 & 0,16 & 0,09 & 0,07 & 0,19 & 0,00 & 0,00 & 0,21 & 0,00 & 0,09 & 0,05 & 0,07 & 0,05 \\
\hline $\mathrm{CaO}$ & 0,38 & 0,46 & 0,40 & 0,42 & 0,42 & 0,48 & 0,31 & 0,42 & 0,31 & 0,34 & 0,19 & 0,39 & 0,33 \\
\hline $\mathrm{Na} 2 \mathrm{O}$ & 1,66 & 2,83 & 3,66 & 3,63 & 4,12 & 3,50 & 3,63 & 3,54 & 3,56 & 3,01 & 2,91 & 4,19 & 3,54 \\
\hline К2O & 6,56 & 6,69 & 5,16 & 5,09 & 5,35 & 5,08 & 4,78 & 5,10 & 4,61 & 5,62 & 6,02 & 4,87 & 4,98 \\
\hline Sum oxides & 100,00 & 100,00 & 100,00 & 100,00 & 100,00 & 100,00 & 100,00 & 100,00 & 100,00 & 100,00 & 100,00 & 100,00 & 100,00 \\
\hline $\mathrm{H} 2 \mathrm{O}$ & 5,47 & 5,50 & 4,37 & 4,55 & 4,33 & 6,50 & 3,88 & 4,34 & 3,58 & & & & \\
\hline $\mathbf{Q}$ & 41,43 & 30,49 & 34,06 & 33,37 & 28,68 & 34,07 & 36,36 & 34,30 & 38,14 & 37,54 & 36,21 & 33,01 & 37,07 \\
\hline Or & 38,78 & 39,51 & 30,48 & 30,08 & 31,63 & 30,05 & 28,23 & 30,13 & 27,25 & 33,18 & 35,59 & 28,77 & 29,45 \\
\hline$A b$ & 14,04 & 23,98 & 30,98 & 30,75 & 34,82 & 29,58 & 30,75 & 29,94 & 30,15 & 25,50 & 24,60 & 35,46 & 29,95 \\
\hline An & 1,87 & 2,26 & 2,00 & 2,08 & 2,10 & 2,36 & 1,55 & 2,07 & 1,56 & 1,68 & 0,95 & 0,57 & 1,65 \\
\hline Cor & 2,05 & 0,96 & 0,68 & 1,57 & 0,24 & 1,86 & 1,26 & 1,22 & 1,36 & 0,66 & 0,85 & 0,00 & 0,46 \\
\hline $\mathrm{IIm}$ & 0,22 & 0,16 & 0,18 & 0,24 & 0,16 & 0,20 & 0,10 & 0,59 & 0,80 & 0,16 & 0,13 & 0,15 & 0,16 \\
\hline Mt & 0,19 & 0,25 & 0,17 & 0,22 & 0,25 & 0,23 & 0,20 & 0,20 & 0,16 & 0,13 & 0,15 & 0,16 & 0,13 \\
\hline Di & 0,00 & 0,00 & 0,00 & 0,00 & 0,00 & 0,00 & 0,00 & 0,00 & 0,00 & 0,00 & 0,00 & 1,19 & 0,00 \\
\hline Hy & 1,45 & 2,40 & 1,46 & 1,70 & 2,14 & 1,66 & 1,57 & 1,56 & 0,60 & 1,15 & 1,54 & 0,71 & 1,13 \\
\hline
\end{tabular}

Table 3 


\begin{tabular}{|c|c|c|c|c|c|c|c|c|c|c|c|}
\hline & \begin{tabular}{|l|} 
Biotites \\
\end{tabular} & & & & & & & Amphiboles & & & \\
\hline $\begin{array}{c}\text { unit } \\
\text { sample } \\
\text { analysis } n_{\mathbf{i}}\end{array}$ & $\begin{array}{c}\text { Perrier II } \\
\text { Matrix } \\
\text { MD10-6 } \\
1705-53\end{array}$ & $\begin{array}{c}\text { Perrier } 1 \\
\text { Matrix } \\
\text { MD10-5 } \\
1705-63\end{array}$ & $\begin{array}{c}\text { Fohet } \\
\text { Pumice } \\
\text { MD12-1P } \\
\text { MD 12 1P_1 }\end{array}$ & $\begin{array}{l}\text { Rochefort-S } \\
\text { Pumice } \\
\text { MD11-8P } \\
\text { MD 11 8P_5 }\end{array}$ & $\begin{array}{l}\text { Rochefort-S } \\
\text { Pumice } \\
\text { MD11-7P } \\
\text { MD 11 7P_11 }\end{array}$ & $\begin{array}{c}\text { Roche Fes } \\
\text { Matrix } \\
\text { MD14-27 } \\
\text { MD14-27-21 }\end{array}$ & & $\begin{array}{l}\text { Rochefort-S } \\
\text { Pumice } \\
\text { MD11-7P } \\
\text { MD 11 7P_6 } \\
\text { green }\end{array}$ & $\begin{array}{c}\text { Perrier I } \\
\text { Matrix } \\
\text { MD10-5 } \\
1705-81 \\
\text { brown }\end{array}$ & $\begin{array}{c}\text { Fenestre } \\
\text { Matrix } \\
\text { MD10-19 } \\
\text { MD 10 19_4 } \\
\text { green }\end{array}$ & $\begin{array}{l}\text { Perrier II } \\
\text { Matrix } \\
\text { MD10-6 } \\
1705-42 \\
\text { brown }\end{array}$ \\
\hline $\begin{array}{l}\mathrm{SiO} 2 \\
\mathrm{TiO} 2 \\
\mathrm{Al} 2 \mathrm{O} 3 \\
\mathrm{FeO} \\
\mathrm{MnO} \\
\mathrm{MgO} \\
\mathrm{CaO} \\
\mathrm{Na} 2 \mathrm{O} \\
\mathrm{K} 2 \mathrm{O} \\
\mathrm{F} \\
\text { TOTAL }\end{array}$ & $\begin{array}{c}35,44 \\
3,48 \\
15,24 \\
16,67 \\
0,39 \\
13,18 \\
0,00 \\
0,53 \\
9,46 \\
\text { n.d. } \\
94,39\end{array}$ & $\begin{array}{c}34,15 \\
4,51 \\
18,67 \\
19,92 \\
0,27 \\
6,73 \\
0,00 \\
0,16 \\
9,47 \\
\text { n.d. } \\
93,88\end{array}$ & $\begin{array}{c}37,14 \\
4,86 \\
12,83 \\
16,02 \\
0,35 \\
14,16 \\
0,03 \\
0,58 \\
8,98 \\
1,57 \\
96,52\end{array}$ & $\begin{array}{c}36,73 \\
5,36 \\
13,60 \\
14,85 \\
0,43 \\
13,05 \\
0,00 \\
0,60 \\
8,53 \\
0,70 \\
94,05\end{array}$ & $\begin{array}{c}33,77 \\
3,13 \\
18,03 \\
20,02 \\
0,14 \\
7,89 \\
0,00 \\
0,14 \\
8,85 \\
1,47 \\
93,50\end{array}$ & $\begin{array}{c}37,61 \\
4,20 \\
17,22 \\
14,10 \\
0,68 \\
11,98 \\
0,00 \\
0,55 \\
7,17 \\
0,94 \\
94,45\end{array}$ & & $\begin{array}{c}49,50 \\
0,62 \\
4,90 \\
12,57 \\
1,82 \\
13,27 \\
9,89 \\
1,90 \\
0,69 \\
1,10 \\
96,29\end{array}$ & $\begin{array}{c}49,33 \\
0,69 \\
4,15 \\
13,14 \\
4,01 \\
14,15 \\
9,24 \\
2,33 \\
0,56 \\
\text { n.d. } \\
97,59\end{array}$ & $\begin{array}{c}49,81 \\
0,55 \\
4,29 \\
11,88 \\
2,26 \\
15,52 \\
10,56 \\
1,64 \\
0,50 \\
1,05 \\
98,09\end{array}$ & $\begin{array}{c}39,28 \\
5,38 \\
13,50 \\
11,20 \\
0,28 \\
13,03 \\
11,73 \\
2,25 \\
1,35 \\
\text { n.d. } \\
98,00\end{array}$ \\
\hline $\mathrm{Si}$ & 5,43 & 5,32 & 5,62 & 5,62 & 5,36 & 5,62 & $\mathrm{Si}$ & 7,43 & 7,32 & 7,33 & 5,82 \\
\hline $\mathrm{Ti}$ & 0,40 & 0,53 & 0,55 & 0,62 & 0,37 & 0,47 & AIIV & 0,57 & 0,68 & 0,67 & 2,18 \\
\hline AIIV & 2,17 & 2,15 & 1,83 & 1,77 & 2,26 & 1,91 & SumT & 8,00 & 8,00 & 8,00 & 8,00 \\
\hline AIVI & 0,59 & 1,28 & 0,46 & 0,68 & 1,11 & 1,12 & AIVI & 0,29 & 0,04 & 0,08 & 0,18 \\
\hline $\mathrm{Fe}$ & 2,14 & 2,60 & 2,03 & 1,90 & 2,66 & 1,76 & Ti & 0,14 & 0,15 & 0,12 & 1,20 \\
\hline $\mathrm{Mg}$ & 3,01 & 1,56 & 3,19 & 2,97 & 1,87 & 2,67 & $\mathrm{Mg}$ & 2,97 & 3,13 & 3,40 & 2,88 \\
\hline$M n$ & 0,05 & 0,04 & 0,05 & 0,06 & 0,02 & 0,09 & $\mathrm{Fe}$ & 1,60 & 1,67 & 1,40 & 0,74 \\
\hline $\mathrm{Ca}$ & 0,00 & 0,00 & 0,01 & 0,00 & 0,00 & 0,00 & SumC & 5,00 & 5,00 & 5,00 & 5,00 \\
\hline $\mathrm{Na}$ & 0,16 & 0,05 & 0,17 & 0,18 & 0,04 & 0,16 & $\mathrm{Fe}$ & $-0,02$ & $-0,04$ & 0,07 & 0,65 \\
\hline \multirow[t]{2}{*}{ K } & 1,85 & 1,88 & 1,73 & 1,66 & 1,79 & 1,37 & $\mathrm{Mn}$ & 0,23 & 0,50 & 0,28 & 0,03 \\
\hline & & & & & & & & 1,79 & 1,54 & 1,65 & 1,32 \\
\hline site IV & 8,00 & 8,00 & 8,00 & 8,00 & 8,00 & 8,00 & SumB & 2,00 & 2,00 & 2,00 & 2,00 \\
\hline site VI & 5,79 & 5,47 & 5,73 & 5,61 & 5,66 & 5,63 & $\mathrm{Ca}$ & $-0,20$ & $-0,07$ & 0,01 & 0,55 \\
\hline \multirow[t]{2}{*}{ site alc } & 2,01 & 1,93 & 1,91 & 1,84 & 1,84 & 1,52 & $\mathrm{Na}$ & 0,55 & 0,67 & 0,47 & 0,65 \\
\hline & & & & & & & K & 0,13 & 0,11 & 0,09 & 0,26 \\
\hline XMg & 0,58 & 0,38 & 0,61 & 0,61 & 0,41 & 0,60 & SumA & 0,48 & 0,71 & 0,58 & 1,45 \\
\hline Xal & 0,10 & 0,23 & 0,08 & 0,12 & 0,20 & 0,20 & $\mathrm{XMg}$ & 0,65 & 0,66 & 0,70 & 0,67 \\
\hline Phlog & 52,54 & 28,80 & 56,25 & 53,58 & 33,15 & 48,25 & & & & & \\
\hline Ann & 37,30 & 47,86 & 35,71 & 34,22 & 47,20 & 31,87 & & & & & \\
\hline East & 5,94 & 8,77 & 4,92 & 7,44 & 8,11 & 11,97 & & & & & \\
\hline Sid & 4,22 & 14,58 & 3,12 & 4,75 & 11,54 & 7,91 & & & & & \\
\hline
\end{tabular}

Table 4 


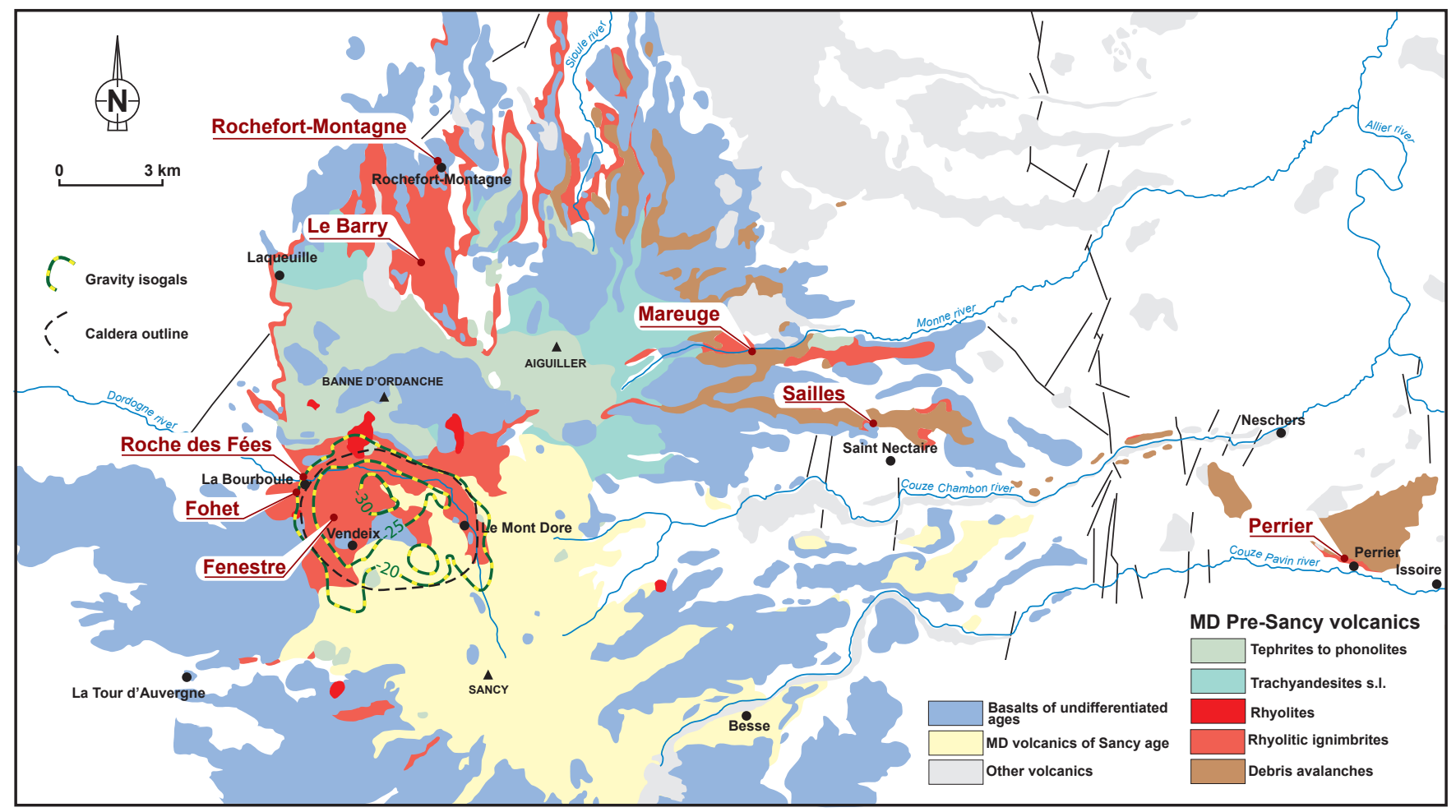



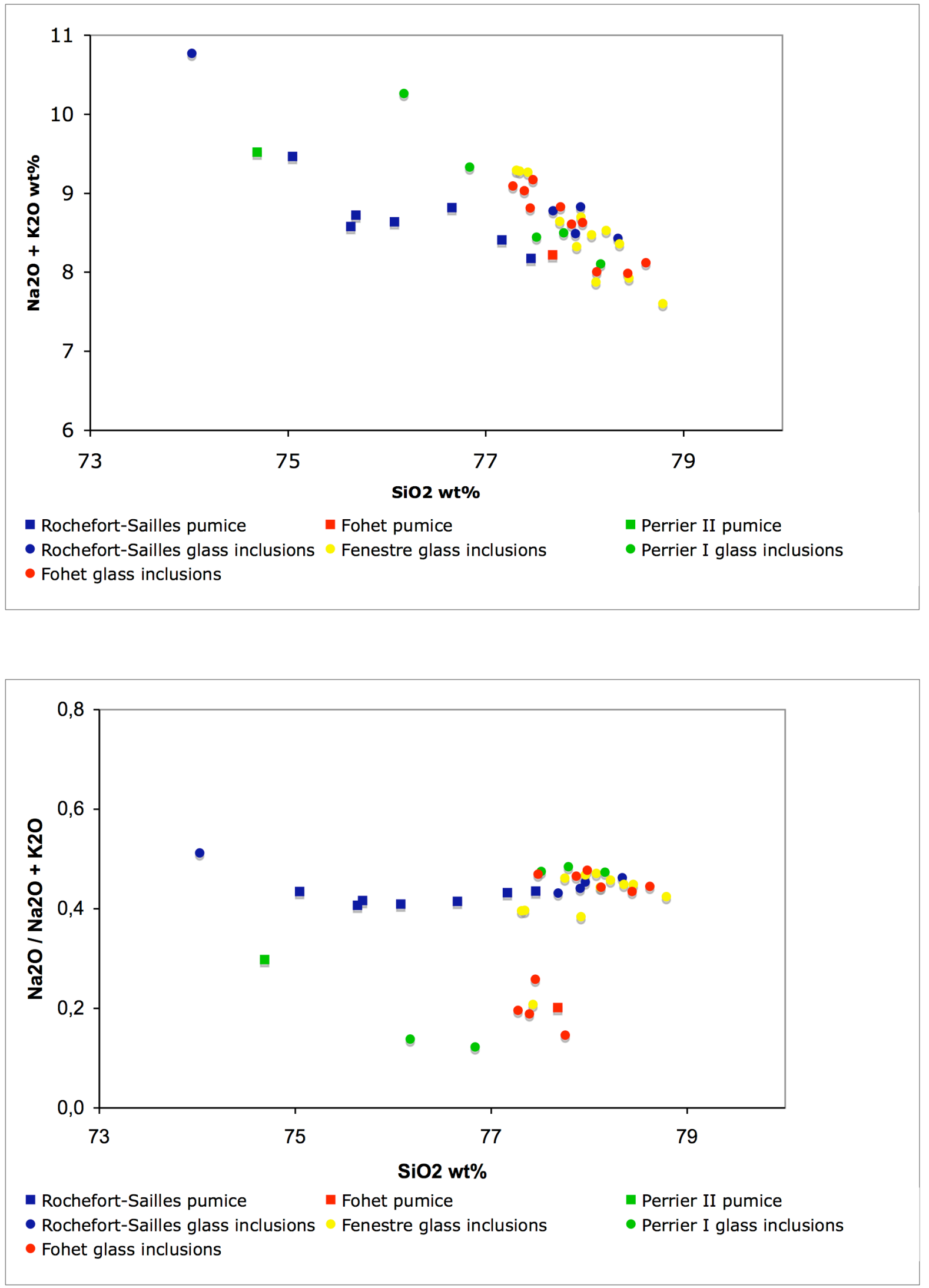

Fig. 2 


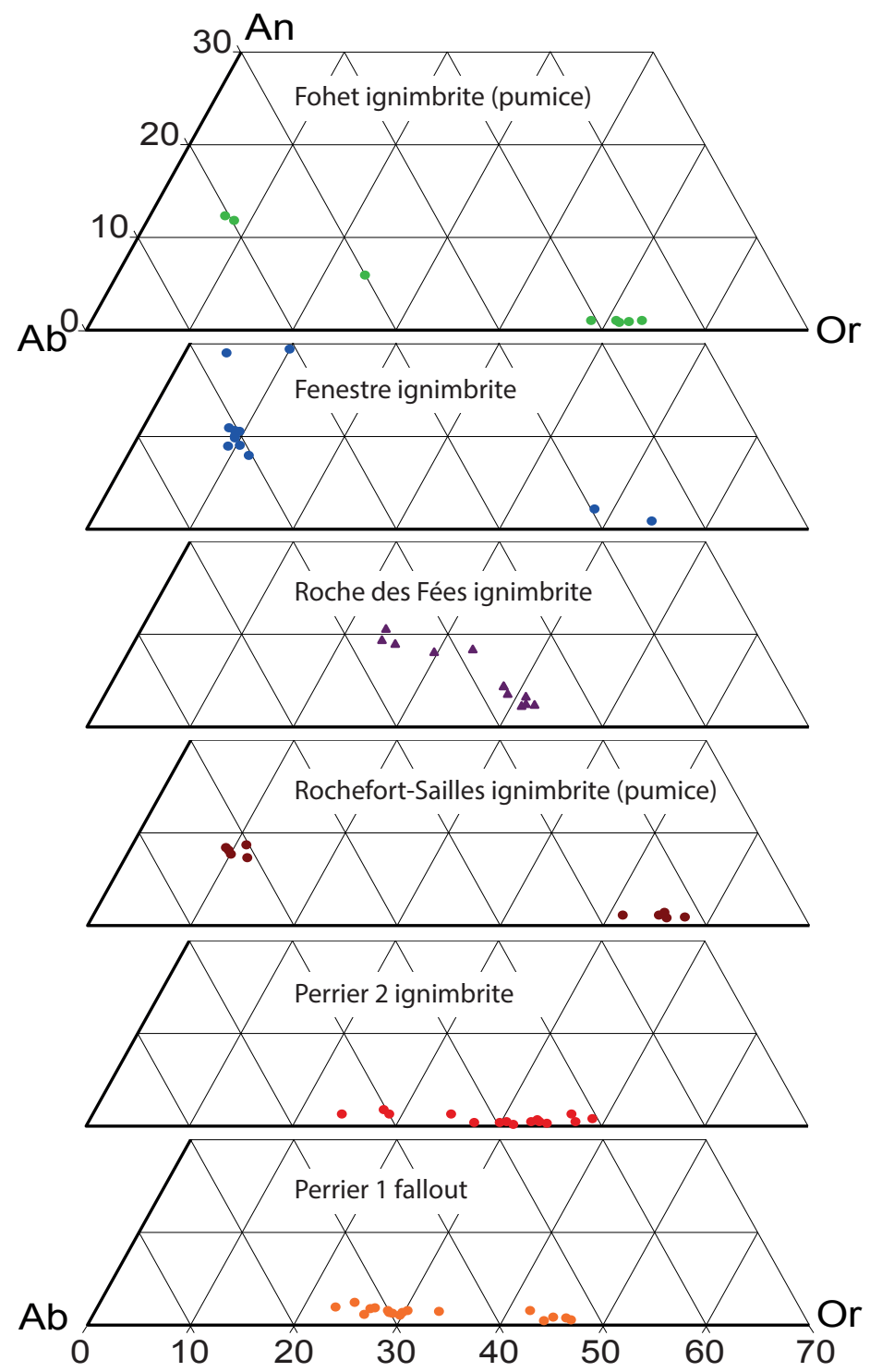




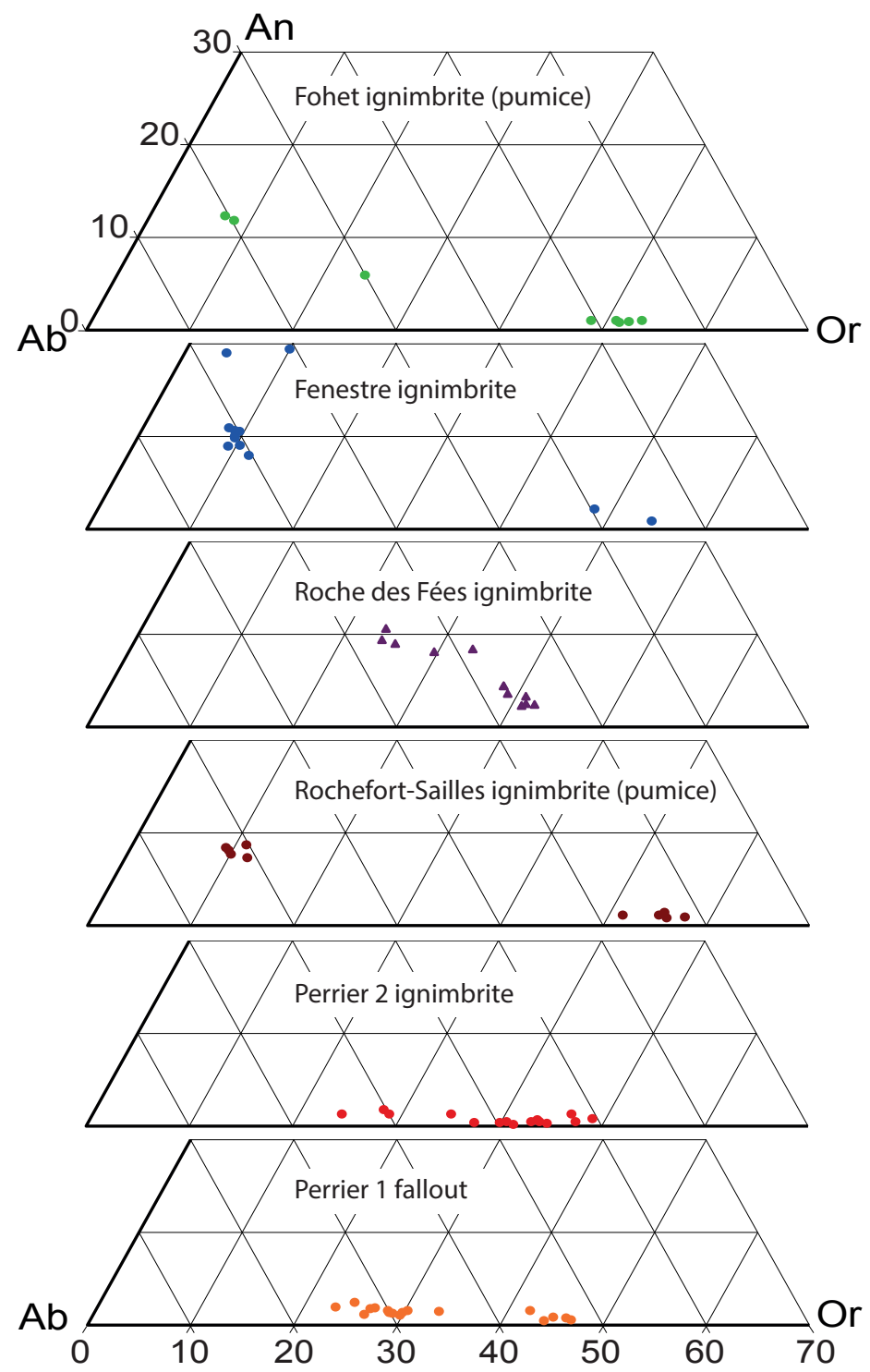



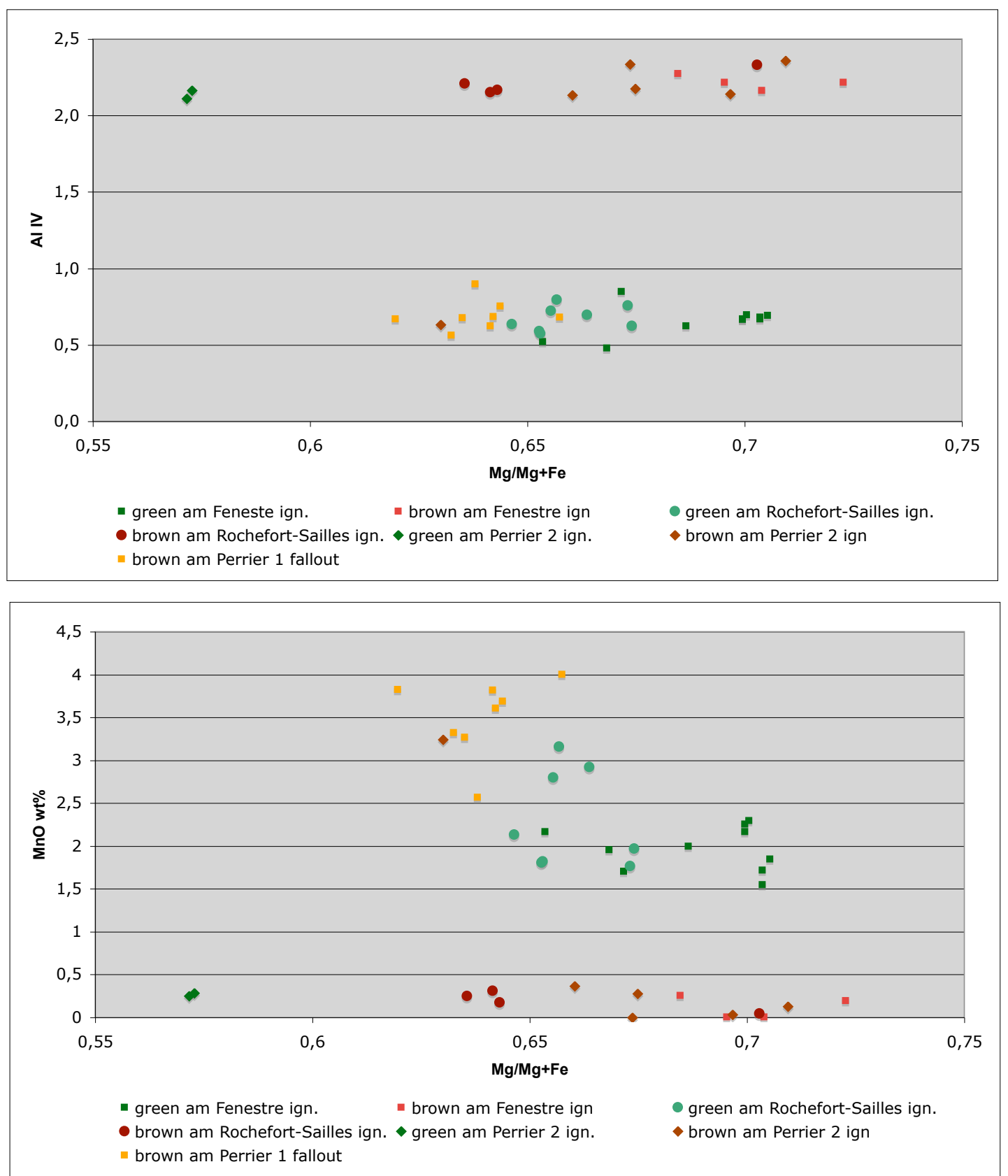


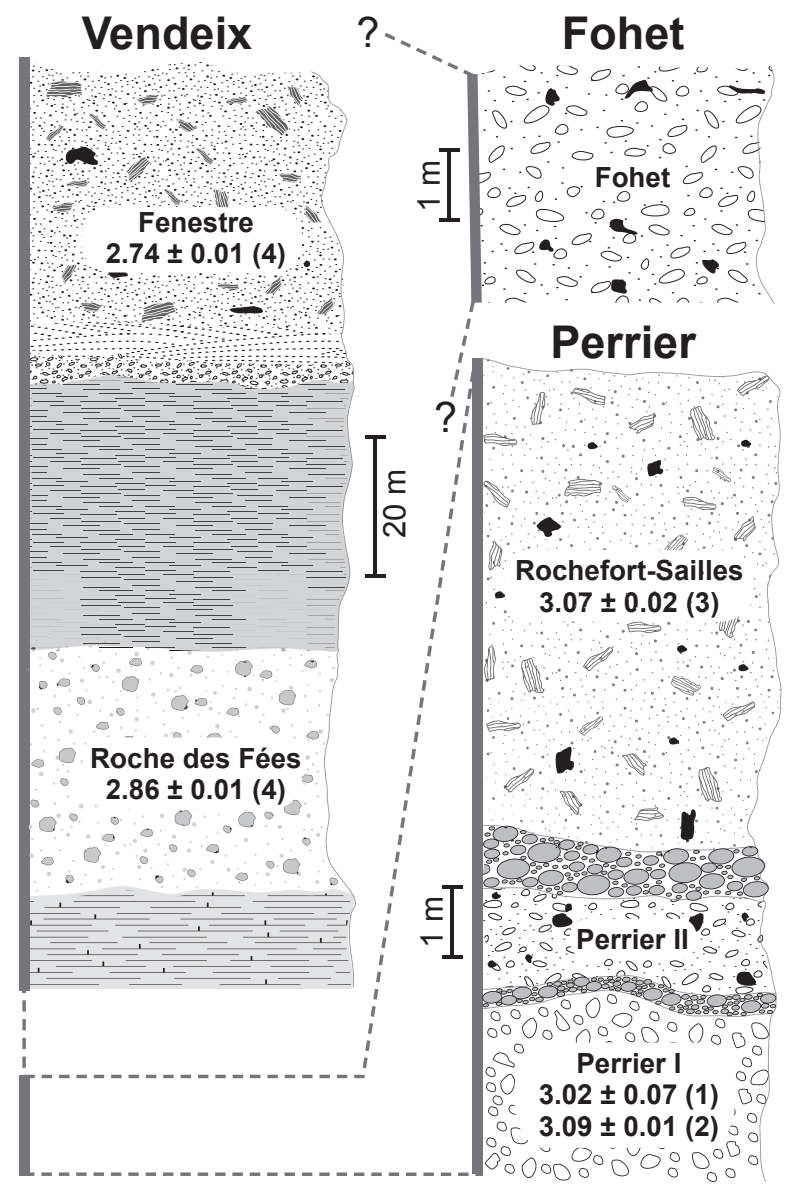

